\title{
Unemployment in Kosovo in the Last Ten Years 2002-2012
}

\author{
Besnik Desku, Msc. (candidate) \\ besi_947@hotmail.com \\ Behrije Ramaj, Phd. (candidate) \\ behrije_ramaj@hotmail.com
}

Doi:10.5901/mjss.2013.v4n10p191

\begin{abstract}
Unemployment is defined as by the Bureau of Labor Statistics (BLS) as people who do not have a job, have actively looked for work in the past four weeks, and are currently available for work. Also, people who were temporarily laid off and are waiting to be called back to that job are included in the unemployment statistics. Those who have not looked for work within the past four weeks are not only no longer counted among the unemployed, they are also removed from the labor force by the BLS. Most people leave the labor force when they retire, go to school, have a disability that keeps them from working, or have family responsibilities. However, even people who would like to work are excluded if they aren't actively looking for work. Unemployment is an important statistic used by the government to gauge the health of the economy. If unemployment gets too high (around 6\% or more), the government will try to stimulate the economy and create jobs. This paper will address the causes of unemployment in the region of Kosovo, Nationally, unemployment is caused when the economy slows down, and businesses are forced to cut costs by reducing payroll expenses. Unemployment can also be caused by competition in specific industries or companies. Advanced technology, such as computers or robots, cause unemployment by replacing worker tasks with machines. The study will be carried out in the region of Kosovo. It will also have its basis in a series of data from various institutions Kosovos. We will deliver questionnaires citizens to know arysen why are not employed and are still waiting to be changes in this respect. Will develop research for finding new programs for the elimination of unemployment. This paper investigates how macroeconomic policy shocks in Kosovo affect the total unemployment and provides evidence on the differential responses of the unemployment by sectors of economic activity. Will present the results of which sector is the largest number of unemployed in the region of Kosovo, which is the strategy of the Ministry of Finance, Ministry of Trade and transport to alleviate unemployment.In this paper we present a model of countries in the region that has applied a macroeconomic policy for reducing unemployment.
\end{abstract}

Keywords: Unemployment, Macroeconomic policy, Economic activity, Causes

\section{Introduction}

Considering the fact that unemployment is a very important actors that indicates the level of economic development of a country and is a serious disease which economic due to its negative effects are quite severe in a country's economy, the unemployment rate is an indicator of economic welfare in general. A low level is indicative of a strong economy where job seekers can find it quickly, while a high level may indicate a weaker economy. Unemployment is a major challenge for all countries face especially in transition countries as our country. So one of the issues of concern in today's society is papunësia.Në This paper will try to examine topics related to unemployment. And will focus on the analysis of labor market data on unemployment in Kosovo from 2000 onwards. Unemployment is one of the most serious diseases macro. Often times, increasing unemployment indicator is considered as a symptom of recession phase.Therefore, theoretical analysis it takes a special importance, because it allows us to determine right and" appropriate " medication" to cure this disease. Unemployment Costs Classified into two main groups:

a) The Economic Costs of Unemployment

b) Social Costs of Unemployment

\subsection{The Economic Costs of unemployment.}

From the point of view economically high Unemployment Means the actual decline in GDP then actual GDP indicator is 
less than potential GDP indicator. As Greater Unemployment, the Greater Will Be the gap between actual GDP and potential GDP.

The Economic cost of Unemployment expressed in macroeconomic perspective, the output gap, ie diferncën between actual and potential product.

One Other aspect Which show Unemployment Costs, is the fact that 'the Unemployed are a heavy Financial Burden for the government, it is the Latter That supports Financial Aid award funds for the Unemployed.

\subsection{Social Costs of Unemployment.}

In addition to Economic Costs, Unemployment accompanied by social Costs, Which, although it is difficult to express in value, are no less Important than social parat.Kostot Unemployment may appeare in. Several forms:

a) Unemployment causes impairment of human capital.

b) Increased Unemployment Can Serve as a warm bed to Increase kr-iminalitetit Nationwide

c) Social Costs of Unemployment Also take the form of reducing the personal Dignity and deteriorated health of Unemployed

\section{Measurement of unemployment}

Two main features of an economic recession are the decline in GDP and sit-tja unemployment. Changes in production are measured by calculating the GDP, while the changes in measured unemployment are measured by calculating the unemployment rate.At a given time, an individual may be busy with work, unemployed or outside the labor force.Busy with work (papunësua) is considered a person who commits a paid job, even if temporarily absent from work because it is I sëmunurë, holiday or strike. Unemployed are those people who are at work but not actively seeking work, or who expect to return we work. More complete definition a person is unemployed if that does not work well:

a) has made specific efforts to find a job during the last four weeks

b) is fired and expect to be called back on the job

c) is waiting bjoftohet for a new job in the next month.

Plus employees are unemployed workforce.

\subsection{Types of unemployment}

In economic literature distinguished several types of unemployment, among them the most important are:

\subsubsection{Unemployment sticking (friksionale)}

This type of unemployment occurs because there is a permanent mobility of people between different countries and regions work.

\subsubsection{Structural unemployment}

This type of unemployment occurs when there is a long-term structural mismatch between supply and demand for labor.

\subsubsection{Cyclical unemployment}

This type of unemployment resulting from the general deficiency of aggregate demand. It is known that the demand for labor is a derived demand.

\subsubsection{Seasonal unemployment}

Seasonal unemployment is related to seasonal character of production. This form of unemployment appears in the branches of the construction industry, agriculture, services, tourism, etc.. 


\subsubsection{Voluntary and involuntary unemployment, are notions used by JM Keynes.}

Involuntary unemployment according to his means the share of the working-age population, which willingly wants to work, for reasons that need not or refuses to work with the salary level offered

\section{Labor market indicators in Kosovo from 2001-2009}

Statistical Office of Kosovo (SOK) has done a survey on the labor market (in December 2001), where the unemployment rate in Kosovo is estimated to be $57 \%$. Hello students labor market indicators from this survey are presented to the table below.

Due to the lack of studies and in order to provide a clearer picture for the labor market, Riinvest Institute undertook this research. To define whether an unemployed person is using the criterion that a person is looking for work. Moreover, a person person is unemployed if he / she is of working age and located in Kosovo. These criteria are important because families surveyed were also asked përnumrin of people that they have migrated. Of the 8,552 persons who survey provides data, 4,937 persons were of working age and in Kosovo. The table below shows the key indicators of the labor market in Kosovo from two sources, the poll of polls and from the Statistical Office of Kosovo (SOK). The latter was carried out in December 2001. In polls survey, respondents were asked several times if they have done any work during a given period of time so that they provide for family consumption. Unemployment and other labor market indicators are defined based on these answers.

Table 1: Indicators of the Labour Market

\begin{tabular}{|l|ccc|ccc|}
\hline & \multicolumn{3}{|c|}{ Rinvest Survey } & \multicolumn{3}{c|}{ ESK Survey } \\
\cline { 2 - 7 } & Total & Female & Male & Total & Female & Male \\
\hline Employment to population of working age & 29.5 & 14.8 & 45.1 & 20.0 & 8.2 & 31.8 \\
The unemployed to the working age population & 28.4 & 25.8 & 31.2 & 26.7 & 19.2 & 34.2 \\
Activity Rate & 58.0 & 40.6 & 76.3 & 46.7 & 27.4 & 66 \\
Employment Rate & 51.0 & 36.4 & 59.2 & 42.9 & 30.1 & 48.3 \\
Unemployed Rate & 49.0 & 63.6 & 40.8 & 57.1 & 69.9 & 51.7 \\
\hline
\end{tabular}

Source: Household Survey,Rinvest ,December 2002; ESK, December 2001

By Rinvestit survey shows that the unemployment rate in Kosovo is 49\%, and it is higher than unemployment in Eastern European countries. After Kosovo, FYR Macedonia that has high unemployment rate (34\% in 2001). However, care should be taken in comparing unemployment rates between different countries as different methodologies used.

Very high rate of unemployment in Kosovo can be explained by the fact that throughout the 1990s has dominated a repressive situation and the war in 1999, who have limited economic growth as the main determinant of unemployment. On the other hand, massive removal of workers from work in the early 1990's and the lack of institutional support ot the development of the private sector contributed to the high rate of unemployment.

\section{Labour market indicators in Kosovo 2009}

First important indicator of the labor market is the relative size of the working age population, such as persons aged between 15 and 64 years, which approximately defines the potential available workforce. In Kosovo, this figure according to AFP SOK 2009 is comparatively low with only $64.0 \%$. The reason for this becomes apparent by looking at the age structure. Kosovo has a relatively "young", with almost a third of the population under age 15 and $7.8 \%$ of the population over age 65 . Such a structure is typical for classical population pyramid. 
Figure 1: Average size of one-year age groups by gender, 2009

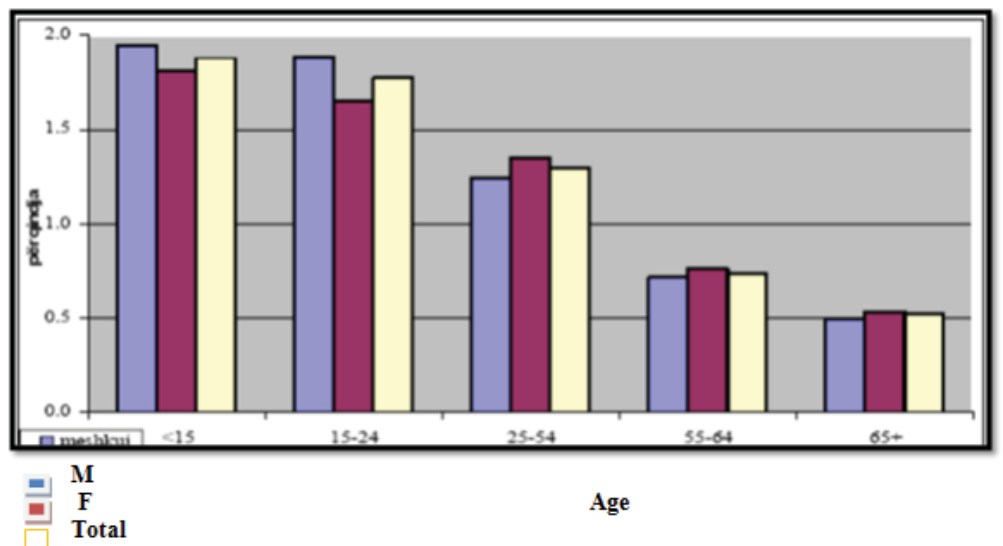

The same facts are presented by dependency rates of youth and old age, which describes how many people under the age of 15 and over the age of 65 , for every 100 people of working age. These comparisons show that for young people the ratio is approximately $1: 2$, but for seniors only $1: 10 .{ }^{1}$

\section{Activity status}

The second group of key indicators of the labor market refers to the actual activity of the population, distinguishing between three statuses: / employed / unemployed, and inactive (e) (for the relevant definitions, see Figure 1 above). the distribution of males, females and total population by activity status is presented in Figure 2 .

Figure 2: Population by employment status and gender, 2008 to 2009

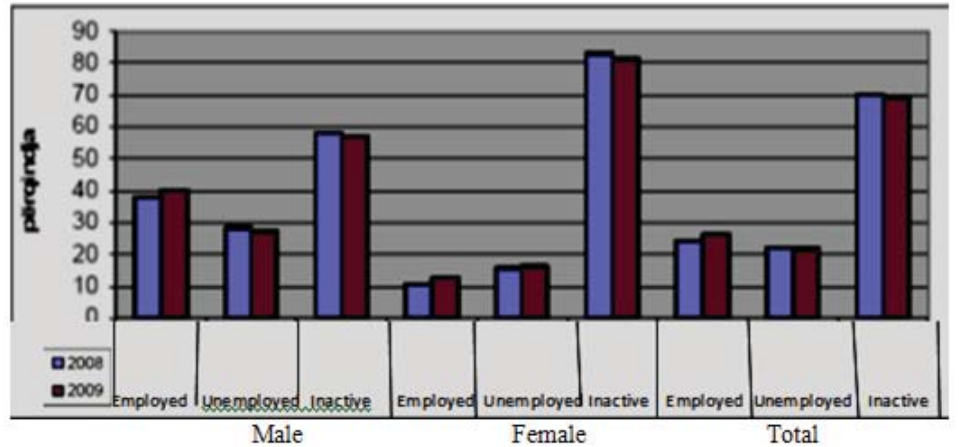

Here contribute to several factors, such as: first, included are all persons under the age of 15 by definition, secondly, many young people are still being educated, thirdly, a number of older persons leave the labor forcebefore reaching the age limit working. Fourth, many women take on family and household responsibilities are not engaged in any economic activity, and, lastly, some people of both sexes have given up looking for work because they believe no work is available.To attach figures last factors, however, would require additional data or analysis. These findings are substantiated by the employment, unemployment and activity, that generally are computed only for the working age population (see Figure 3$)^{2}$

\footnotetext{
1 www.ks-gov.net/esk

${ }^{2}$ www.ks-gov.net/esk
} 
Figure 3: Share of working age population in the labor market by gender, $2008-2009$

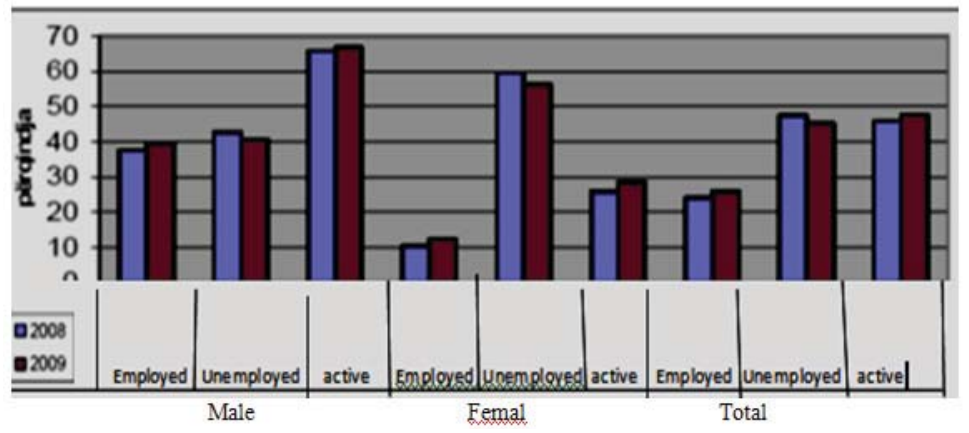

Almost $40 \%$ of Kosovo males of working age, were actually employed in 2009 , the corresponding figure for women is about $13 \%$, with the overall rate lies somewhere in between and is over $26 \%$.

\section{Unemployment data for the year $\mathbf{2 0 1 0}$}

With a total of 335,260 people registered as unemployed in the public employment services in Kosovo until the end of 2010 - representing a decrease of $-1.1 \%$ compared to 2009. Similar to the previous year, the registered unemployed represent a degree of unemployment registration approximately $37-41 \%$ of the population economically aktive.Mbi $90 \%$ of the registered unemployed are long-term unemployed (12 months +). Approximately $47.9 \%$ of the registered as unemployed are women. If compared with 2009, the number of registered women is decreasing by about $-0.2 \%$. The unemployment rate among women is about $55-58 \%$, while the unemployment rate for men is about $28-32 \%$. Approximately $60 \%$ of the registered unemployed refer to the qualification level of education as "unskilled". The number of unemployed in this group of qualifications is decreasing by about $-1.5 \%$. More than $72 \%$ of all registered unemployed belong to a school under the education level mesme.Grup young - 15-24 years old - face the highest level of entries in unemployment (2.4\%). average, an employment officer in Kosovo in 2010 has had to care for unemployed 1842:

This is more than 12 times than the average Evropiane.Me a placement rate of more than $25.3 \%$, and the unemployed with university degree have faced more favorable situation compared to other qualification levels: the unemployed "unqualified" have reached a placement rate of $1.4 \%$ in 2010 , while the employment rate of women unemployed "unskilled" is down $0.67 \%$. Unemployed women with university diploma level has reached the level of employment prejrreth $33.7 \%$. While Albanians achieve a placement rate of about $2.01 \%$, and other Kosovo minorities achieve a placement rate of $2.65 \%$. Unemployment in the 15-24 year-old has reached the scale with the highest activation (1.55\%) and the highest proportion (49.4\%) of all participants in training for 2010.

\section{Registered unemployment by skills}

Comparison of levels of qualification in 2007/09 unemployed persons "unskilled) in 2010 still represents the highest proportion total number of unemployed people $(60 \%)$ and the rate in registrations $(-1.5 \%)$.

At the same time the level of qualifications again represents the highest number of new registrations (9999 people) - having fallen by an average of $-3.9 \%$ from the total number of entries compared with last year's entries (tabela. 2 and fig. 2). as the only group of qualified, unemployed at the level of qualification "semi skilled" an increase of (18.4\%) in comparison with the previous year, while the group of "qualified", represents a decrease in the number recordings ($16 \%)$, which probably also refers to administrative changes with regard to institutional definitions qualification levels. Despite a linear correlation that remains in terms of qualification levels and unemployment growth (fig. 2), a closer look of the resulting figures in 2010, as in 2009, presented a continuous segmentation of labor Kosovar market. 2). Qualifications as to be high ("high school" and "university") face: the highest average monthly entry as well as the highest average monthly outflow, showing dynamic on the proportion of the labor market, respectively lower risk to remain unemployed (long-term). While calculative proportion of long-term unemployment in Kosovo is $87 \%$ on average, the proportion of long-term unemployment calculative referring to higher qualification levels is about $70 \%$ in average. 
Table 2: Unemployment by qualifications

\begin{tabular}{|c|c|c|c|c|c|c|c|}
\hline Qualification & ISCED & $\begin{array}{c}\text { Registered } \\
\text { unemployment }\end{array}$ & $\%$ & $\begin{array}{l}12 \text { monthly } \\
\text { Inflows }\end{array}$ & $\begin{array}{l}\text { Exits } 12 \\
\text { Months }\end{array}$ & $\begin{array}{l}\text { Shl Monthly } \\
\text { average }\end{array}$ & $\begin{array}{c}\text { ShE Monthly } \\
\text { average }\end{array}$ \\
\hline Prequalified & $0-2$ & 200709 & 60 & 9999 & 13054 & $0.41 \%$ & $0.54 \%$ \\
\hline $\begin{array}{c}\text { Semi } \\
\text { Qulifaction }\end{array}$ & 3 & 12594 & 4 & 424 & 1185 & $0.27 \%$ & $0.77 \%$ \\
\hline Qualified & $3 a$ & 28353 & 8 & 705 & 1201 & $0.21 \%$ & $0.35 \%$ \\
\hline $\begin{array}{l}\text { Secondary } \\
\text { schools }\end{array}$ & $3 c$ & 87874 & 26 & 6560 & 6367 & $0.62 \%$ & $0.61 \%$ \\
\hline High school & 4 & 2155 & 1 & 171 & 200 & $0.66 \%$ & $0.78 \%$ \\
\hline University & $5 a+$ & 3575 & 1 & 2055 & 1542 & $5.20 \%$ & $3.90 \%$ \\
\hline
\end{tabular}

Source: Unemployment by MPMS qualifications / DPP / Labour and Employment Kosovë.2010 Registered unemployment by age

Regarding unemployment by age, the majority of the unemployed $(148,059)$ Accumulated figures still refer to the age of 25-39vjecar. However, a comparison of directly the total figures by age suffer from the number of different years in terms of coverage in any age group.

Table 3: Unemployment by age

\begin{tabular}{|c|c|c|c|c|c|c|}
\hline AGE & $\begin{array}{c}\text { Registered } \\
\text { unemployment }\end{array}$ & $\%$ & $\begin{array}{c}12 \text { monthly } \\
\text { inflows }\end{array}$ & $\begin{array}{c}\text { exits 12 } \\
\text { months }\end{array}$ & $\begin{array}{c}\text { Shl Monthly } \\
\text { average }\end{array}$ & $\begin{array}{c}\text { ShE Monthly } \\
\text { average }\end{array}$ \\
\hline $15-24$ & 106342 & $32 \%$ & 7705 & 5259 & $0.61 \%$ & $0.42 \%$ \\
\hline $25-39$ & 148059 & $44 \%$ & 8375 & 9698 & $0.47 \%$ & $0.54 \%$ \\
\hline $40-54$ & 63631 & $19 \%$ & 2822 & 5010 & $0.36 \%$ & $0.65 \%$ \\
\hline $55-64$ & 17228 & $5 \%$ & 1012 & 3582 & $0.47 \%$ & $1.66 \%$ \\
\hline
\end{tabular}

\section{Registered unemployment by ethnicity}

A presentation by ethnicity census followed the first priority goal qetekrahasoheni developments in comparative form in terms of access that minorities in Kosovo services employment. The 2010 growth rate in Records presents the results in a decrease for all the registered unemployed. Serb community undergoes a decrease of about $-1.3 \%$ Other minorities also registered with $-3.8 \%$ and for the Albanians of registered decline in enrollment is less sensitive by about $-0.9 \%$ (see fig. 4).

Fig.4. 12-Month growth rate by Ethnicity

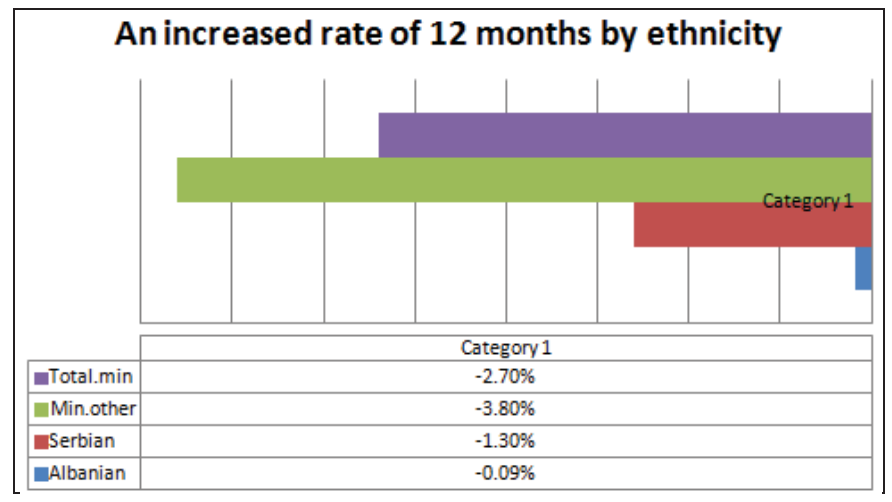

Source: Monthly growth rate MPMS / DPP / Labour and Employment Kosovë.2010 


\section{Conclusion}

Based on all this that shqyrova so far in this paper has left to figure out that unemployment is a" disease" against which try to fight everyone, but no matter how big and powerful be it nevertheless attempts develops and makes its own. Unemployment is a serious disease which is associated macroeconomic and other negative consequences. Unemployment is not a phenomenon that affects only poor countries, but it affects everyone, and consequences, especially in developing countries and that causes a negative phenomenon, as well as macroeconomic state. Also I tried to focus somewhat and labor market related data on unemployment in Kosovo during the last decade. By Rinvestit survey shows that the unemployment rate in Kosovo is $49 \%$, and it is higher than unemployment in Eastern European countries. After Kosovo, FYR Macedonia that has high unemployment rate (34\% in 2001). However, care should be taken in comparing unemployment rates between different countries as different methodologies used. Almost $40 \%$ of Kosovo males of working age, were actually employed in 2009 , the corresponding figure for women is about $13 \%$, with the overall rate lies somewhere in between and is over $26 \%$.". The number of unemployed in this group of qualifications is decreasing by about $-1.5 \%$. More than $72 \%$ of all registered unemployed belong to a school under the education level mesme.Grup young - 15-24 years old - face the highest level of entries in unemployment (2.4\%). average, an employment officer in Kosovo in 2010 has had to care for unemployed 1842

\section{References}

Grup autoresh, Hyrje në Ekonomi ( 2000) Kreu XIX , Tiranë , Stefan ,Qiric (2005) : Ekomiksi i Punës, Tiranë www.ks-gov.net/esk www.mpms-ks.org www.riinvestinstitute.org 